\title{
Methyl-3 Hydroxy-6 Quinazoline Dione-2-4, a New Compound for Labelling Plant Cells Application to the Study of Two Inhibitors of Cytokinesis
}

\author{
G. Deysson, M.-J. Lasselain and C. Pareyre \\ Laboratoire de Biologie cellulaire-UER des Mécanismes d'Action des Médicaments \\ et des Toxiques, Faculté des Sciences Pharmaceutiques et Biologiques \\ et EPHE, 4, Avenue de l'Observatoire, 75270 Paris Cedex 06, France
}

Received February 24, 1979

Cells of experimental materials such as tissue cultures or root-tips divide asynchronously. In order to determine accurately the sensitivity of each stage to exogenous substances, it is necessary to synchronize the cell population or, alternatively, to label the cells at a particular stage of the mitotic cycle.

In plant roots, a partial synchronization of cell division can be obtained by exposing the material to an inhibitor of DNA synthesis such as OH-urea (Brulfert and Deysson 1973) or 5-amino uracile (Jacob and Trosko 1965, Mattingly 1966, Prensky and Smith 1965, Wagenaar 1966), but the kinetic parameters of the synchronous cell populations thus obtained are modified and these populations are made up of cells whose metabolism is disturbed; synchronous cell populations thus obtained have modified kinetic parameters, and are made up of cells whose metabolism is disturbed; moreover, no single synchronizing agent allows experimentation on all the phases of the mitotic cycle.

Several methods of labelling cells have been devised. One of them is the labelling of cells in $\mathrm{S}$ using ${ }^{14} \mathrm{C}$ or ${ }^{3} \mathrm{H}$ thymidine; with these methods the use of autoradiography is necessary (Taylor 1960, Wimber and Quastler 1963). Another one is the labelling of cells by treatment with spindle poisons such as colchicine (Östergren and Wakonig 1954, Van'T Hof et al. 1960) or (in plant material) with inhibitors of cell plate formation such as methylated purines (e.g. caffeine, theophylline, 8-ethoxycaffeine) (Gimenez-Martin et al. 1966, Kihlman 1955). As a result of these treatments, cells with a double set of chromosomes or binucleate cells are formed. These morphological labellings are easily carried out but may have the disadvantage of either greatly disturbing the cellular morphology or of modifying the kinetics of the labelled cells. Moreover, the cells thus marked are not really synchronous: they are only at the same place in the mitotic cycle at the time of labelling.

In this article, we study the use of methyl-3 hydroxy- 6 quinazoline dione-2-4 (MHQD) as a morphological labeller. This molecule causes the immediate appearance of binucleate cells, without disturbing the structure and the kinetics of cells thus marked. If certain precautions are taken, it also allows experiments to be carried out on each of the three periods of interphase. This method of morphological labelling may, therefore, be generally applied to the study of inhibitors of cell proliferation. 
After studying the cytotoxicity of MHQD, we shall define the kinetic characteristics of the sample of labelled cells populations and give two examples of the application of this method to the study of the action of caffeine and deoxyguanosine $(\mathrm{GdR})$ on each phase of the cell cycle.

\section{Materials and methods}

Allium sativum L. meristem cells were used. The roots were taken after two days germination in a thermostatic chamber $\left(20-22^{\circ} \mathrm{C}\right)$ in a $50 \%$ Knop solution. ${ }^{1}$ Only the meristem tip was used. In all experiments, the meristems were fixed and stained in acetic orcein for 24 hours before being squashed. All experiments were carried out with a half saturated solution of MHQD $\left(2.5 \times 10^{-7} \mathrm{~mol} / \mathrm{ml}\right)$ in the $50 \%$ Knop solution; the MHQD is dissolved in warm liquid but care is taken not to reach boiling point.

\section{Cytotoxicity of MHQD; formation of binucleate cells}

Two treatments with MHQD were used:

- continuous treatment with renewal of the solutions as soon as the substance begins to precipitate (approximately every four hours).

- one hour treatment followed by return to Knop's medium. With the latter, an experiment was carried out on meristems which had already been synchronized with $\mathrm{OH}$-urea $\left(7.5 \times 10^{-6} \mathrm{~mol} / \mathrm{ml}\right)$ during one cell cycle ( 23 hours) then returned to the $50 \%$ Knop solution (Brulfert and Deysson 1978); 10 hours after the return, the synchronized cells were exposed to the action of MHQD for one hour, during their passage into mitosis.

In all cases, the variations in three parameters were observed: the mitotic index, the index of the different phases of mitosis and the index of binucleate cells.

\section{Study of cells pulse-labelled with $M H Q D$}

Only the one hour treatment was used. The autoradiographic study was carried out with ${ }^{3} \mathrm{H}$ methyl-thymidine (NEN, Boston Mas., U.S.A.) at a concentration of $4 \mu \mathrm{Ci} / \mathrm{ml}$ (specific activity $25 \mathrm{Ci} / \mathrm{Mmole}$ ). We used the method of repeated pulse labelling $(15 \mathrm{mn})$ followed by three washings $(3 \times 5 \mathrm{mn})$ with "cold" thymidine ten times more concentrated $\left(4.1 \times 10^{-8} \mathrm{~mol} / \mathrm{ml}\right)$. The meristem samples were then taken immediately.

In the same experiment, three parameters were determined in order to follow the labelled cells throughout the mitotic cycle: the index of telophases without phragmoplast, the index of binucleate cells and the index of double prophases. These index were determined on a minimum of 100 cells. Four meristems were examined when each sample was taken.

Moreover, DNA synthesis was followed through the variations in the intensity of labelling (measured in 100 nuclei of binucleate cells for each sample).

$1 \mathrm{Ca}\left(\mathrm{NO}_{3}\right)_{2}, 1 \mathrm{~g} ; \mathrm{KNO}_{3}, \mathrm{KH}_{2} \mathrm{PO}_{4}, \mathrm{MgSO}_{4}, 0.25 \mathrm{~g} ; \mathrm{FeCl}_{3}, 0.005 \mathrm{~g}$; distilled water 1 litre. 
Action of caffeine and GdR on the cell cycle

The telophases which had already begun were labelled with MHQD ( $1 \mathrm{hr}$ ) then returned to the $50 \%$ Knop solution. The cells thus labelled were treated with GdR $\left(2 \times 10^{-6} \mathrm{~mol} / \mathrm{ml}\right)$ or with caffeine $\left(4.6 \times 10^{-6} \mathrm{~mol} / \mathrm{ml}\right)$ during their passage into $G_{1}, S, G_{2}$ and $M$ as shown in the following table ( $T=$ length of treatment, $R=$ length of return in Knop's medium after labelling with MHQD).

\begin{tabular}{|c|c|c|c|c|c|c|c|c|}
\hline & & $\mathrm{G}_{1}$ & & $\mathbf{S}$ & & $\mathrm{G}_{2}$ & & M \\
\hline \multirow[t]{2}{*}{ GdR } & $\mathbf{R}$ & $\mathrm{O}$ & $\mathbf{R}$ & $4 \mathrm{~h}$ & $\mathbf{R}$ & $21 \mathrm{~h}$ & $\mathbf{R}$ & $23 \mathrm{~h}$ \\
\hline & $T$ & $4 \mathrm{~h}$ & $\mathrm{~T}$ & $\ldots 11 \mathrm{~h}$ & $\mathrm{~T}$ & $4 \mathrm{~h}$ & $T$ & $3 \mathrm{~h}$ \\
\hline \multirow[t]{2}{*}{ Caffeine } & R & $\mathrm{O}$ & $\mathbf{R}$ & $4 \mathrm{~h}$ & $\mathbf{R}$ & $\ldots \ldots 15 \mathrm{~h}$ & $\mathrm{R}$ & $23 \mathrm{~h}$ \\
\hline & $T$ & $\ldots 4 \mathrm{~h}$ & $T$ & .. $11 \mathrm{~h}$ & $T$ & $\ldots \ldots \quad 4 \mathrm{~h}$ & $\mathrm{~T}$ & $3 \mathrm{~h}$ \\
\hline
\end{tabular}

The beginning of the treatment of the $G_{2}$ phase was carried out later with $G d R$, taking into account the slowing down of this phase under the influence of $G \mathrm{~d} R$ (Lasselain et al. 1978); if the treatment had begun sooner, it would not have been possible to observe the passage in $M$ under the conditions of the experiment. According to this methodology, the treatment of the phase of the cell cycle sensitive to the action of these compounds should induce (or bring about immediately in the case of $\mathrm{M}$ ) the appearance of tetranucleate cells (or trinucleate cells, after the fusion of the two central nuclei) (see Figs. 5 and 6).

\section{Results}

\section{Cytotoxicity of MHQD. Formation of binucleate cells}

\section{1) Action of $M H Q D$ in continuous treatment (see Fig. 1)}

The continuous treatment with MHQD brings about important variations in the mitotic index: first, an important decrease in the mitotic index was observed, which was progressive and transitory, with its maximum after $8 \mathrm{hr}$; the mitotic index then rose, reaching twice the normal values after $15 \mathrm{hr}$, then finally became stable after $18 \mathrm{hr}$.

During this treatment, the distribution of the different phases of mitosis was not significantly modified, which indicated that MHQD mainly causes a slowing down followed by a uniform acceleration in the kinetics of the whole of the cell population.

Finally, it was observed that the formation of binucleate cells takes place progressively and continuously, except after $8 \mathrm{hr}$ treatment, when the curve deviates slightly; this variation corresponds to the maximum of the decrease in the mitotic index. After $24 \mathrm{hr}$ treatment, the index of binucleate cells approached $30 \%$.

It must be remembered that the continuous treatment was carried out with solutions which were renewed every four hr. If a continuous twenty-four hr. treatment is carried out without taking this precaution, the MHQD partially precipitates in microcrystals and the results are then completely different: there is no longer any difference in the mitotic index. This peculiarity has led one of us to propose a method of determining the length of mitosis. Thanks to this method, the infuence of an inhibitor on this phase may be followed at any time during the treatment (Deys- 
son and Chaouat, 1973).

2) Action of $M H Q D$ on a wave of synchronized mitoses

An hr treatment with MHQD on a wave of synchronized mitoses resulted in a significant increase in the number of binucleate cells $(10 \%)$. This result may be compared with the delay in the appearance of these cells in a normal population (Deysson 1969) and proves that MHQD acts immediately at the moment of cell
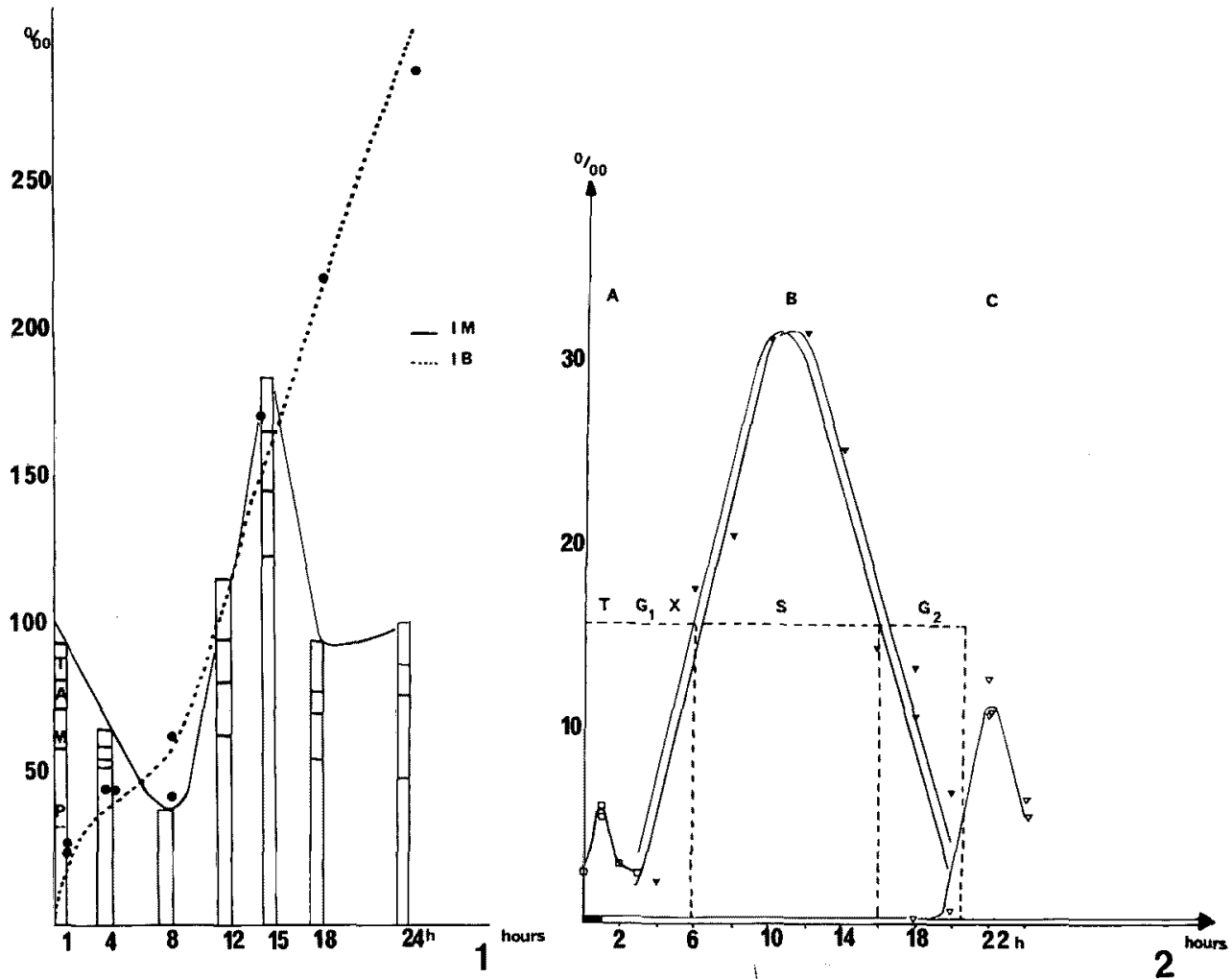

Figs. 1-2. 1, variations of mitotic index and binucleate cells index during continuous treatment by MHQD solutions $(24 \mathrm{mg} / 100 \mathrm{ml})$ renewed every four hours. One can observe: A strong and temporary decrease in the mitotic index with practically no change in the phase repartition.

A gradual accumulation of binucleate cells. (IM, mitotic index; IB, binucleate cells index). 2, kinetics of the binucleate cells during the interphase (see text). ${ }^{*} \mathrm{~A}$ : Index of telophases without

phragmoplast. B: Index of labelled binucleate cells. $\mathrm{C}$ : Index of double prophases.

*The values as read on curve $B$ are corrected taking into account the duration of pulse labelling.

division. It must be noted that, although these binucleate cells are more numerous, they are useless as a sample of labelled cell population since the chemical synchronization has disturbed their kinetic parameters.

Study with a sample of cell population labelled with a pulse MHQD treatment

1) Modalities of morphological labelling of the cells at the end of mitosis (see Fig. 2A)

The MHQD prevents the normal formation of phragmoplast during telophase. The cells which undergo morphological labelling are, therefore, first of all the telo- 
phases already underway. After $0 \mathrm{hr}, 2.4$ telophases without phragmoplast per 1000 cells were found; they were at the beginning of the telophase and the phragmoplast was not yet visible with an optical microscope. After $1 \mathrm{hr}$ treatment with MHQD, the index reached its highest value (5.8 telophases without phragmoplast per 1000 cells) but it came back to its initial value only $1 \mathrm{hr}$ after the return to Knop's solution. This shows that a certain number of cells which were in metaphase and anaphase at $0 \mathrm{hr}$ must have been labelled morphologically.
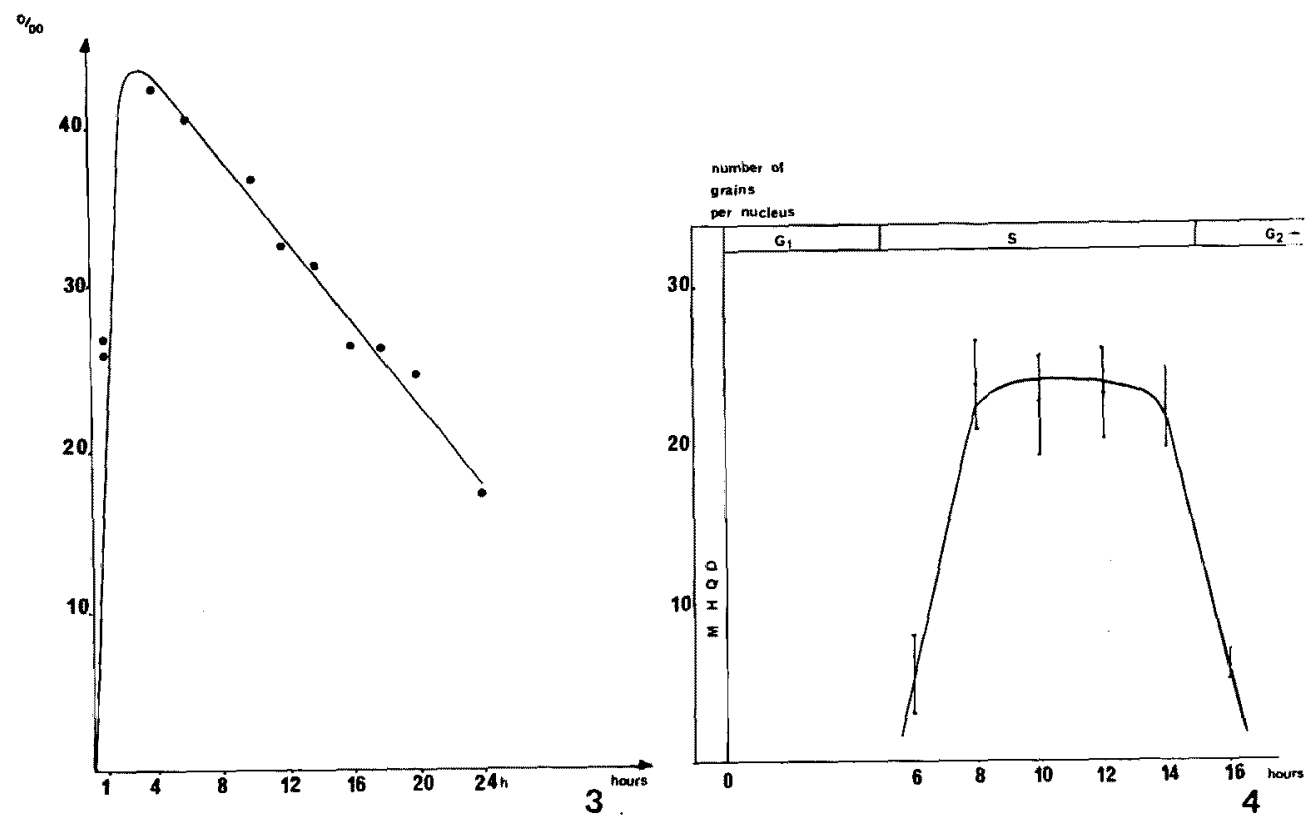

Figs. 3-4. 3, gradual decrease in binucleate cells index after recovery. 4, rate of DNA synthesis in the binucleate cells. Notice at 6 and $16 \mathrm{hr}$ the slight labelling intensity. This peculiarity tends to prove that both at the beginning and at the end of $S$, the binucleate cells remain relatively synchronous. The length of binucleate cells interphase is represented by the bar in the upper part of the figure.

2) Progression of binucleate cells through the interphase (see Figs. 2A, B and C) The evolution of three parameters is shown in Fig. 2: the index of telophases without phragmoplast (A), the index of labelled binucleate cells (B) obtained by the repeated pulse labelling method and the index of double prophases (C).

Between the $\mathrm{Y}$ axis and the point half-way up the curve of labelled binucleate cells, a period of six hr is obtained, which theoretically corresponds to the length of telophase $+\mathbf{G}_{1}$. But, in fact, this period also includes a margin of error, corresponding to the inaccuracy of labelling.

Half-way up the wave of binucleate cells, the value of $S$ is seen as ten $\mathrm{hr}$, whereas the length of $G_{2}$, measured half-way up curves $B$ and $C$ is $4.8 \mathrm{hr}$.

Finally, the length of the interphase, taken between the $\mathrm{Y}$ axis and the point half-way up the curve of double prophases is $20.8 \mathrm{hr}$. 
The values thus obtained for $S, G_{2}$ and the whole interphase correspond to the values usually found with our material (Deysson and Bonaly 1970, Pareyre and Deysson 1975). The value of telophase $+G_{1}$ is also normal, given the inaccuracy of the morphological labelling, which is about $1 \mathrm{hr}$ (see Fig. 2). Thus the length of telophase $+G_{1}=5$ hours, which is similar to that found using the direct method suggested in our laboratory (Benbadis et al. 1971, Pareyre and Deysson 1975).

In conclusion, it appears that the kinetic parameters of the sample of cell population having undergone morphological labelling are not significantly modified.

\section{3) Progressive loss of binucleate cells (see Fig. 3)}

Five hr after the return to Knop's solution, there was a slight decrease in the index of binucleate cells and this decrease became more and more important throughout the experiment. The sample of labelled cell population was thus reduced from 42.5 per 1000 (maximum obtained after $3 \mathrm{hr}$ ) to 17.6 per 1000 after $24 \mathrm{hr}$. The slope of the curve shows that the loss of binucleate cells takes place gradually throughout the cell cycle, not during any one given period.

4) DNA synthesis in the binucleate cells (see Fig. 4)

The determination of the labelling intensity for each sample proves that this synthesis takes place continuously during $\mathrm{S}$, with a constant level. The total absence of action of MHQD on DNA synthesis must be compared with the variations noted during a treatment with caffeine, used under the same conditions of morphological labelling (Fernandez-Gomez 1968).

The samples taken $6 \mathrm{hr}$ and $16 \mathrm{hr}$ after the return to Knop's solution had a labelling intensity well below that of the others. These two points, in fact, correspond to the entrance into and exit from the $S$ phase of all the binucleate cells: in view of the length of the labelling and washings ( $30 \mathrm{mn}$ in all), certain cells can enter into and leave $\mathrm{S}$ whilst under the influence of the radioactive precursor; they will thus be more slightly labelled. This peculiarity concerns all of the binucleate cells, which tends to prove that both at the beginning and end of $S$, they remain relatively synchronous.

Application of morphological labelling to the study of two inhibitors of cytokinesis (GdR and caffeine). (see Figs. 5 and 6)

The treatment of binucleate cells with GdR or caffeine during the passage into $\mathrm{G}_{1}$ has no after-effects (Figs. 5B and 6B).

The treatment of the $\mathrm{S}$ phase brings about, in both cases, a significant slowing down. After a treatment with GdR, the first double prophases only appear $37 \mathrm{hr}$ after labelling, that is after a delay of $14 \mathrm{hr}$; after the caffeine treatments, they appear $31 \mathrm{hr}$ after labelling, that is after an eight-hour delay (Figs. $5 \mathrm{C}$ and $6 \mathrm{C}$ ).

However, neither GdR nor caffeine bring about the formation of tetranucleate cells when they are applied during the $G_{1}$ or $S$ phases.

If $\mathrm{GdR}$ affects the $\mathrm{G}_{2}$ stage, it has not only a significant delaying effect (the onset of double prophases is $5 \mathrm{hr}$ late) but also an inhibiting effect on cytokinesis which results in tetranucleate and trinucleate cells (Fig. 6D), whereas the treatment of double mitoses has no after-effects whatsoever (Fig. 6E). 
In the case of caffeine, the treatment of the $\mathrm{G}_{2}$ phase only brings about a slight delay (Fig. 5D) whereas the treatment of double mitoses is followed by an inhibition of cytokinesis which is almost immediate (Fig. 5E).

a
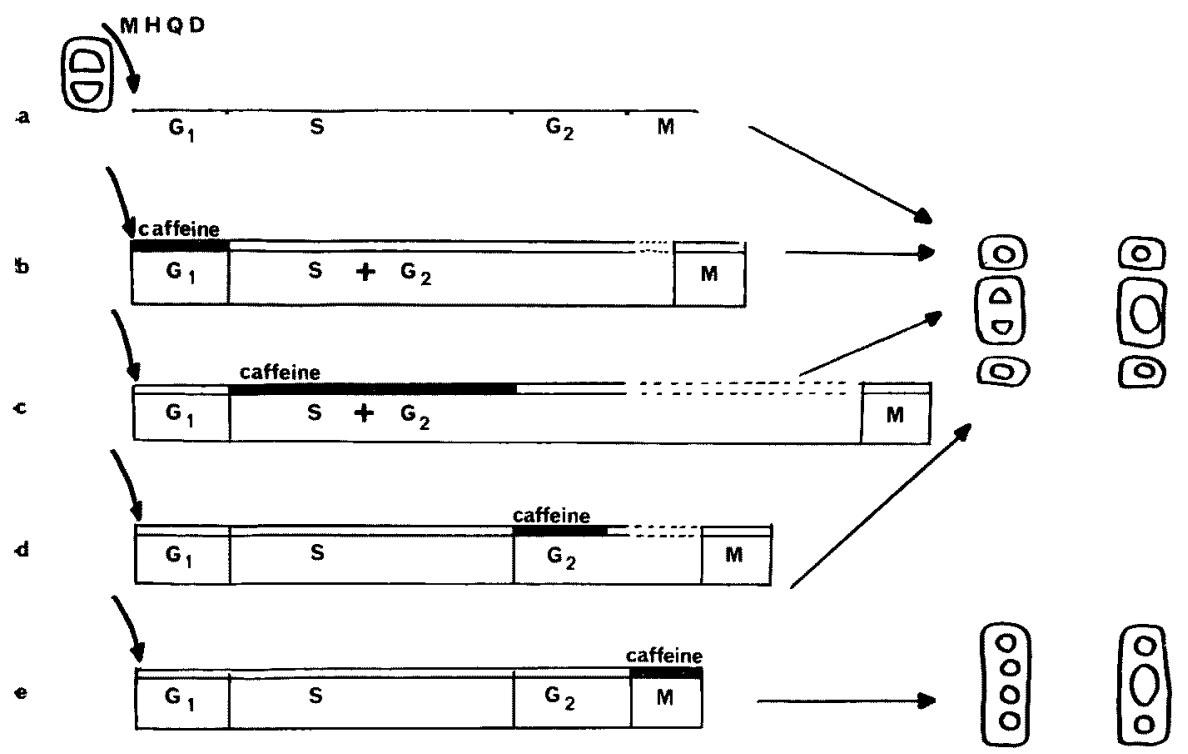

a $M+Q D$

01
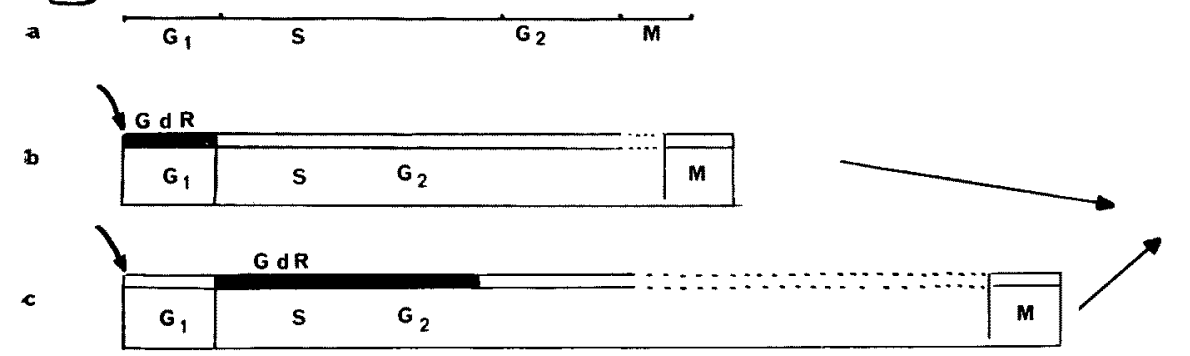

(2) (O)

(0) 0

()
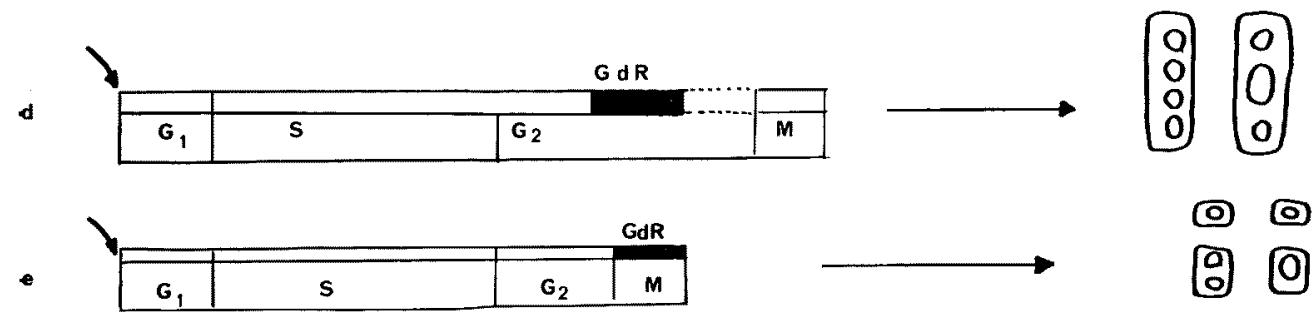

(๑)

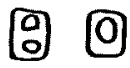

(ㄷ)

6

Figs. 5-6. 5, determining the site of action of caffeine through the morphological labelling method. a) Mean durations of $G_{1}, S, G_{2}$ and $M$ in the control. b, c and d) Treatments of $G_{1}, S$ or $G_{2}$ and formation of mono and binucleate cells (see test). e) Treatment of $M$ and formation of tri and tetra nucleate cells (see text). 6, determining the site of action of GdR through the morphological labelling method. a) Mean durations of $G_{1}, S, G_{2}$ and $M$ in the control. b, $c$ and e) Treatments of $G_{1}, S$ or $M$ and formation of mono and binucleate cells (see text). d) Treatment of $G_{2}$ and formation of tri and tetra nucleate cells (see text). 


\section{Discussion and Conclusion}

So that a molecule may be used as a morphological labeller, it must conform to certain criteria:

- the morphological labelling must be instantaneous and very precisely limited.

- the cytotoxicity of this molecule must be as limited as possible, both at the cell population level (the kinetic parameters must remain normal) and at the level of the individual cell (more especially in cases where labelling gives binucleate cells, the two nuclei must pass through the cycle synchronously).

- the natural scattering of labelled cells (which are not really synchronized) during the cell cycle should not be such that it interferes with the interpretation. - finally, for as brief a period of labelling as possible, the number of labelled cells should be sufficient, the ideal case being that all the cells at the phase in the cycle on which the molecule acts, are labelled.

First, the point up to which these criteria are respected in the case of labelling with MHQD, is examined, then through the study of GdR and caffeine, the limitations of this methodology of studying the action of an inhibitor on the three periods of interphase are discussed.

\section{Accuracy of the morphological labelling with $M H Q D$}

A one hour treatment with MHQD labels instantaneously the telophases already underway. But the inhibiting action on the phragmoplast does not stop at the end of this treatment: it persists for approximately one hour. Since there is no modification in the distribution of the different mitotic stages, it may be concluded the length of the telophase is not extended. This means that the action of MHQD continues after the end of the treatment. The hypothesis that the compound induces the inhibition of cytokinesis by affecting the metabolism of cells in prophase or metaphase at $0 \mathrm{hr}$, cannot be dismissed. But it seems more probable that the MHQD is retained in the cells and only begins to be eliminated or destroyed after a certain delay (Deysson 1969).

Thus morphological labelling with MHQD is not ideal as regards accuracy, but it is possible to determine the absolute limits of the period of labelling as the time 0 of the experiment on the one hand, and the end of the first hour after the return to Knop's solution on the other.

Kinetic characteristics of cells labelled with $M H Q D$

The kinetic parameters of cells labelled with MHQD are not different from normal parameters for our material. However, Fig. 2 clearly shows an overlapping of the three periods of interphase for all of these cells.

Two factors are responsible for this:

1) the characteristics of pulse labelling. The extension of the action of MHQD after the return to Knop's solution makes it impossible to experiment specifically on the $G_{1}$ stages; the risk of having treated cells in mitosis will always be present, even before they become binucleate. This relatively lengthy period of labelling (necessary in order to have sufficient labelled cells) will again lead to errors later, when these cells cross the $G_{1} / S$ and $S / G_{2}$ limits. 
2) the natural scattering of cells. The morphological labelling marks the cells which are in telophase at a given moment, but which do not necessarily continue through the cell cycle synchronously. Theoretically, this can be a second cause of error in the specificity of the treatment of labelled cells during any of the three periods of interphase.

However, Fig. 2 shows that no difficulty arises over the treatment of the $\mathrm{S}$ phase, because of its length. Moreover, the study of the intensity of labelling (Fig. 4) clearly shows that at the beginning and end of $\mathrm{S}$, the binucleate cells have remained sufficiently synchronous to have a significant effect on the results. The treatment of the $G_{1}$ and $G_{2}$ phases, however, necessitates a certain number of precautions, according to the inhibitor whose action is to be studied on these phases (see further on).

\section{Asynchronism of the nuclei}

In an earlier paper (Benbadis et al. 1974), using MHQD in a pulse treatment $(1 \mathrm{hr})$, it has been shown that, during the $\mathrm{S}$ phase, the loss of synchronism between the two nuclei of a binucleate cell is prevalent in approximately $20 \%$ of these cells. This loss of uniformity has also been demonstrated by Howard and Deway (1961), on Vicia faba and by Gimenez-Martin et al. (1977) on Allium cepa in binucleate cells obtained with caffeine treatment. It therefore seems that this asynchronism stems neither from the material nor from the inhibitor used. Moreover, the studies of Gimenez-Martin et al. (1977) prove that this asynchronism only appears during the $S$ phase and is practically non-existent during the $G_{1} / S$ and $S / G_{2}$ passages, which corresponds with our observations. It is therefore feasible to suppose that both the nuclei of the binucleate cells are in $G_{1}, S$ or $G_{2}$ at any given moment, and not just one of the two.

\section{Disappearance of binucleate cells}

Two hypotheses, which do not exclude each other, may explain the disappearance of binucleate cells throughout the cell cycle:

First, it is possible that some cells are transformed into tetraploid cells following fusion phenomena. This fusion may take place between two interphasic nuclei, or else during bimitosis, especially during anaphase. The phenomenon has been observed in Vicia faba (Röper 1976) and Allium cepa (Gimenez-Martin et al. 1968) with binucleate cells obtained by a pulse treatment with caffeine.

It is also possible that certain "binucleate cells" actually had a cytokinesis which was considerably delayed but not permanently arrested.

Finally, the effect of dilution of binucleate cells in a proliferous cell population whose mitotic index shows no variation, must be taken into account.

In any case, as this disappearance is gradual, it does not prevent the use of MHQD as a morphological labeller; but because of it, at the end of the experiment there only remains a restricted sample of labelled cells, which tends to reduce the accuracy of the observations. In practice, it is therefore necessary to look for all the labelled cells in each sample, in several meristems. 
Application to the action of GdR and caffeine on the cell cycle-Limitations of the method

The method of labelling with MHQD proves that GdR and caffeine act on two different levels of the cell cycle, as inhibitors of cytokinesis. Although it may not be surprising to note that an inhibitor acts immediately on the telophases already begun, which is the case with caffeine, the results obtained with GdR are much more original. According to these results, GdR represents a new category of cytokinesis inhibitor, whose action disturbs the metabolism in $\mathbf{G}_{2}$, without preventing the entry into mitosis, but preventing, later on, cytoplasmic division. This result may be compared with the information provided by genetic methodologies, which prove the interdependence of events which take place during the cell cycle (Culotti and Hartwell 1971, Hartwell 1971). The work of Hartwell (1971) has shown that, in Saccharomyces cerevisiae, the four genes controlling the cytokinesis have their "execution point" at different moments of the interphase. It may therefore be supposed that in our material, certain genes, which act normally during $\mathrm{G}_{2}$, cannot carry out their functions in the presence of GdR, which must bring about the delayed appearance of binucleate cells.

This result illustrates the practical interest of the method of morphological labelling proposed here. But this method has limitations and certain precautions are necessary to ensure the specificity of the treatment of the different periods of the cell cycle:

- From a general point of view, the relative inaccuracy of labelling means that while trying to treat cells in $G_{1}$, cells in mitosis risk being treated (see higher up). But in the specific case, when the action of the inhibitor is studied, this risk is avoided. If the compound studied induces an inhibition of cytokinesis from the $\mathrm{G}_{1}$ phase, the appearance of tetranucleate or trinucleate cells (after the fusion of the two central nuclei) may be observed. In this case, there can be no possible confusion with cells treated during the mitosis preceding $\mathrm{G}_{1}$.

- The $G_{1} / S$ and $S / G_{2}$ limits are not, theoretically, well defined. But it has already been shown that some of our results could only be interpreted with a rather good synchronism of the sample of binucleate cells during the $G_{1} / S$ and $S / G_{2}$ passages (see labelling intensity). It is, moreover, always possible to use autoradiography to help ensure the specificity of the treatment of $G_{1}, S$ and $G_{2}$.

- Finally, the $\mathrm{G}_{2} / \mathrm{M}$ limit is clearly defined by the sudden appearance of double prophases (see Fig. 2C). It should, moreover, be noted that, when the inhibitor acts on $G_{2}$, it generally causes a slowing down or reversible arrest in this phase, which leaves an important "safety margin" (see, for example, Fig. 6D).

Theophylline (Kilhman 1955) and caffeine (Gimenez-Martin et al. 1965) have already been proposed as morphological labellers for the study of the cell cycle on plant material. In both cases, the authors describe a certain number of advantages:

- possibility of immediate pulse labelling.

- persistence of the synchronism of the labelled population during the cell cycle.

- no modification of the kinetic parameters of this population.

- slight toxicity (under the conditions of pulse labelling) and easy manipulation.

But the cytotoxicity of caffeine has since been the subject of several extensive 
studies, from which it emerges that:

- it modifies the duration of mitosis, especially at the beginning of the treatment. Thus, with our material, an hour's treatment with caffeine almost doubles the length of mitosis (Chaouat and Deysson 1973).

- during the $\mathrm{S}$ phase, there is a transitory but important reduction in DNA synthesis in a sample of binucleate cells, obtained by pulse labelling (FernandezGomez 1968).

MHQD has neither of these disadvantages and combines all the known advantages of this type of morphological labelling. It therefore seems suitable for generalised application as a morphological labeller on one condition: that it does not interact with the compound whose action on the cell cycle is to be studied.

\section{Abstract}

The action of MHQD on a meristematic root cell population of Allium sativum L. has been studied in order to investigate the possibility of using MHQD as a morphological labeller and to specify the advantages and disadvantages of the method.

After a brief treatment, MHQD causes the immediate appearance of binucleate cells. These cells have normal kinetic parameters and there is no significant loss of synchronism between their two nuclei. This sample of labelled cell population goes synchronously throughout the cell cycle. Unlike caffeine, MHQD does not modify the mitosis duration nor the DNA synthesis ratio. Therefore, MHQD seems suitable as a morphological labeller, useful for the study of the action of various cell cycle inhibitors. Two examples of application of this method are given in order to outline its interest.

\section{Literature cited}

Benbadis, M.-C., Levy, F. and Pareyre, C. 1971. Methode de détermination directe de la durée de la période $G_{1}$ du cycle cellulaire dans les méristèmes radiculaires. C.R. Acad. Sci., Paris 273: 352-355.

—, Ribsztejn, M. and Deysson, G. 1974. The mode of nuclear DNA synthesis in experirıentally induced binucleate cells of root meristems. Chromosoma 46:1-11.

Brulfert, A. and Deysson, G. 1973. Synchronisation des divisions des cellules méristématiques d'Allium sativum L. par l'hydroxyurée. Conditions d'application à l'analyse cinétique des effets cytotoxiques. Ann. pharm. fr. 31: 19-27.

Chaouat, L. and Deysson, G. 1973. Influence de la caféine sur la durée de la mitose des cellules végétales. C. R. Soc. Biol., Paris 167: 1745-1749.

Culotti, J. and Hartwell, L. H. 1971. Genetic control of the cell division cycle in yeast III. Seven genes controlling nuclear division. Exper. Cell Res. 67: 389-401.

Deysson, G. 1969. Sur un nouvel inhibiteur de la cytodiérèse des cellules végétales, la méthyl-3 hydroxy-6 quinazoline dione-2-4. C. R. Soc. Biol., Paris 163: 37-41.

- and Bonaly, J. 1970. Modifications expérimentales du cycle cellulaire étudiées sur le méristème radiculaire d'Allium sativum L. I. Détermination du cycle cellulaire normal. Ann. pharm. fr. 28: 605-614.

- and Chaouat, L. 1973. Nouvelles recherches sur l'action inhibitrice de la méthyl-3 hydroxy-6 quinazoline dione-2-4 sur la cytodiérèse des cellules végétales. Durée du cycle cellulaire 
et de la mitose. C. R. Soc. Biol,, Paris 167: 188-192.

Fernandez-Gomez, M. E. 1968. Rate of DNA synthesis in binucleate cells. Histochemie 12: 302-306.

Gimenez-Martin, G., Gonzalez-Fernandez, A. and Lopez-Saez, J. F. 1965. A new method of labelling cells. J. Cell Biol. 26: 305-309.

- - - and - 1966. Duration of the division cycle in diploid, binucleate and tetraploid cells. Exper. Cell Res. 43: 293-300.

-, Lopez-Saez J. F., Moreno, P. and Gonzalez-Fernandez, A. 1968. On the triggering of mitosis and the division cycle of polynucleate cells. Chromosoma 25: 282-296.

—, de la Torre, C. and Lopez-Saez, J. F. 1977. Cell division in higher plants. in Mechanisms and Control of Cell Division. Dowden Hutchinson and Ross Ed. Stroudsburg, Pennsylvania.

Hartwell, L. H. 1971. Genetic control of the cell division cycle in yeast IJ. Genes controlling DNA replication and its initiation. J. Mol. Biol. 59: 183-194.

- 1971. Genetic control of the cell division cycle in yeast. IV. Genes controlling bud emergence and cytokinesis. Exper. Cell Res. 69: 265-267.

Howard, A. and Dewey, D. L. 1961. Non uniformity of labelling rate during DNA synthesis. Exper. Cell Res. 24: 623-624.

Jacob, J. M. and Trosko, J. E. 1965. The relation between 5 amino uracil induced mitotic synchronization and DNA synthesis. Exper. Cell Res. 40: 56-67.

Kilhman, B. A. 1955. Chromosome breakage in Allium by 8 ethoxy caffeine and X-rays. Exper. Cell Res. $8: 345-368$.

Lasselain, M-J., Pareyre, C. and Deysson, G. 1978. Contribution to the understanding of the mechanism of cytokinesis in plant cells: the action of deoxyguanosine on the kinetics of a root meristem cell population. Cell Tissue Kinet. 11: 519-527.

Mattingly, E. 1966. Synchrony of cell division in root 'meristems following treatment with 5 amino uracil. in Cell Synchrony (Cameron, I. L., and Padilla, G. M., edit.). Academic Press, New York.

Östergren, G. and Wakonig, T. 1954. True or apparent sub chromatid breakage and the induction of labile states in cytological chromosome loci. Bot. Notiser 1954: 357-375.

Pareyre, C. and Deysson, G. 1975. Activity of tubulosine on the kinetics of root meristem cell population. Cell Tissue Kinet. 8: 67-79.

Prensky, W. and Smith, H. H. 1965. The mechanism of 5 amino uracil induced synchrony of cell division in Vicia faba root meristems. J. Cell Biol. 24: 401-414.

Röper, W. 1976. Nuclear fusion and irregular cytokinesis in binucleate and tetraploid cells of Vicia faba after caffeine treatment. Experientia 32:1260-1261.

Taylor, J. H. 1960. Asynchronous duplication of chromosomes in cultured cells of chinese hamster. J. Biophys. Biochem. Cytol. 7: 455-463.

Van'T Hof, J., Wilson, G. B. and Colon, A. 1960. Studies on the control of mitotic activity. The use of colchicine in the tagging of a synchronous population of cells in the meristem of Pisum sativum. Chromosoma 11:313-321.

Wagenaar, E. R. 1966. High mitotic synchronization induced by 5 amino uracil in root cells of Allium cepa L. Exper. Cell Res. 43: 184-190.

Wimber, D. E. and Quastler, H. 1963. A thymidine- ${ }^{14} \mathrm{C}$ and ${ }^{3} \mathrm{H}$ double-labeling technique in the study of cell proliferation in Tradescantia root tips. Exper. Cell Res. 30: 8-22. 